\title{
ANALIZA CONTRASTIVĂ - ACTUALITATE ŞI RELEVANȚĂ ÎN PREDAREA LIMBII ROMÂNE CA LIMBĂ STRĂINĂ ÎN ARMENIA
}

\author{
Nicolae Adrian HENT \\ Universitatea Carolină din Praga
}

\begin{abstract}
Rezumat. Când te decizi să înveți o limbă străină, fie într-un cadru organizat, fie în alte contexte, poți fi sigur de un lucru: o să faci greșeli. Vei fi confruntat cu greșeala la început, pe parcurs sau chiar după finalizarea studiului, greșeli de care ești conștient și pe care le vei corecta sau greșeli pe care nici nu le realizezi și a căror sursă nu o cunoști. Eroarea în studierea unei limbi străine este certitudinea care uneori descurajează, alteori ambiționează, o problematică mereu actuală, care a reprezentat de secole punctul de plecare în analiza procesului de achiziție a unei limbi străine, pe lângă rolul esențial pe care îl are în sistemul de feedback al predării-învățării. Privită în ansamblu, istoria, nu foarte lungă, a lingvisticii contrastive se traduce printr-un efort susținut de a-și trasa o identitate bine definită în ansamblul vast al științelor limbii. Lingvistica contrastivă implică, grosso modo, o comparație teoretică, sistematică şi sincronică între două sau mai multe limbi, înrudite sau nu, tipologic asemănătoare sau diferite. Acest articol își propune să abordeze selectiv probleme circumcise lingvisticii contrastiv-tipologice, presupunând examinarea noţiunilor de comparare sincronică, echivalenţă cu scopul de a determinaizomorfismul, respectiv alomorfismul celor două limbi şi identificarea unor metode, structuri relevante pentru un demers didactic coerent, profund, ancorat in limba vorbită, circular şi eficient. Urmând traseul analizei contrastive lucrarea punctează, cu exemple, o serie de diferenţe intre limbile armeană şi română, variind de la lipsa categoriei gramaticale a genului la substantive, de la faptul că unele cuvinte din cele două limbi aparţin unor părţi de vorbire diferite, până la folosirea în contexte gramaticale diferite a articolelor hotărâte şi nehotărâte.
\end{abstract}

Cuvinte cheie: analiză contrastivă, didactică armeană, română, $A L$.

Abstract. This paper is intended to present alternative landmarks in teaching Romanian to Armenian language speakers who do not have another language support in learning. One of the oldest existing languages, an independent branch of the Indo-European languages, Armenian has its own alphabet with more letters than the Romanian one and it is not completely a phonetic language.

Following the pattern of contrastive analysis, this paper points out, with concrete examples, a series of structural differences and similarities between the two languages, ranging from the lack of grammatical category in nouns, from the fact that some words bellong to different parts of speech in Armenian as compared to Romanian, to the use in different grammatical contexts of the definite and indefinite article. 
The paper also outlines some similarities between the two languages, such as the phonemic awarness, the consonants and fricative consonant clusters, mid central closed vowels $(\breve{a}, \hat{a})$, the non-syllabic (glide) ,,$"$ " similar to the one existing in Armenian as it occurs in limited contexts.

The issues realated to morphology and syntax comprise only those aspects that are relevant and may arise difficulties in learning Romanian. The similarities include the rich nominal and verbal flection, marked by numerous alternations, the so called „border word classes" with a fluctuant flexion, the regular structure of the numerals and their formation, the definite article that occurs in the end like in Romanian. Among the differences the most relevant are: the specific regime of the grammatical gender of the nouns, the present subjonctive (future in Armenian), with different grammatical inflection for each person; the ,future compulsive tense", expressed by the modal verb, ,petq e" plus the future subjonctive, the occurence of the ablative, locative, or instrumental case. The paper proves that the pattern of contrastive analysis is both efficient and necessary in this particular didactic approach.

Keywords: contrastive analysis, didactics, Armenian, Romanian, SLA.

Privită în ansamblu, istoria, nu foarte lungă, a lingvisticii contrastive se traduce printr-un efort susținut de a-și trasa o identitate bine definită în ansamblul vast al științelor limbii. Lingvistica contrastivă implică, grosso modo, o comparație teoretică, sistematică și sincronică între două sau mai multe limbi, înrudite sau nu, tipologic asemănătoare sau diferite. Krzesowski (1990: 76) susține că analiza contrastivă presupune compararea sincronică și aplicată a celor cinci nivele ale limbii, urmărind mai ales ,,notarea și descrierea similitudinilor și diferențelor dintre limbi decât gruparea lor genetică și tipologică”.

În anii '50-'60, majoritatea lingviștilor recunoșteau lingvistica contrastivă ca ramură a lingvisticii aplicate. Studiul lui Charles Fries, Teaching and Learning English as a Second Language este considerat o piatră de hotar în recunoașterea teritoriului lingvisticii contrastive ca subramură a lingvisticii: ,the most efficient materials are those that are based upon a scientific description of the language to be learned, carefully compared with a parallel description of the native language of the learner" (Fries, 1945: 176). Un pas important în trasarea granițelor lingvisiticii contrastive și reconsiderarea aportului acesteia în învățarea limbilor străine (binomul limbă maternă-limbă țintă) îl constituie cercetarea lui Robert Lado din 1957, Linguistics across Cultures: Aplied Linguistics for Language Teachers, un studiu fundamental de lingvisitcă contrastivă structuralistă: ,We can predict and describe the patterns that will cause difficulty in learning and those that will not cause difficulty, by comparing systematically the language and culture to be learned with the native language and culture of the student" (Lado, 1957: 43)

Această direcție care mută accentul de pe simpla comparare a fonologiei, a morfologiei, a sintaxei și a lexicului pe analiza discursului ca sistem structural 
contextualizat (pragmatică, stilistică, sociolingvistică) este continuată de Filmore, Remarks on Contrastive Pragmatics, și Ulla Connor, Contrastive Rhetoric: Cross-Cultural Aspects of Second Language Writing. Este necesar să amintim și de influențele descriptivismului american (Sapir, Bloomfield), ale structuralismului european (Bally, 1932) și de rolul cercetărilor fonologice realizate de lingviștii de la Praga.

În Europa, cercetările de lingvistică contrastivă au produs un corpus de studii comparative între diferite perechi de limbi, care a constituit baza de formare a cercetărilor în domeniul achiziției limbilor străine (Second Language Acquisition - SLA). Amintim aici proiectele majore bazate pe contrastivitate: între poloneză și engleză (coordonat de Jacek Fisiak, 1973), germană și engleză (PAKS, coordonator Gerhard Nickel, 1971), sau englezăși sârbo-croată (Filipovic, 1971). În același context trebuie amintite și următoarele cercetări: Filip Devos, de Munynck, van HerrewegheNederlands, Frans en Engels in contrast (1991; 1992); MarlisHellinger, Contrastive Sociolinguistics (1996); James Carl, Contrastive Analysis (1980); Anna Wierzbicka, Cross-Cultural Pragmatics (1992).

Începând cu anii '70, tot mai mulți lingviști pun la îndoială eficiența analizei contrastive în SLA. Cei mai mulți (Corder, 1975; Newmark, 1968; Selinker, 1972) pornesc de la premisa că diferențele majore între două idiomuri nu creează neapărat dificultăți în învățarea unei limbi, ci, dimpotrivă, fenomenele minore, slab contrastante, actionează ca factori care împietează însușirea unei limbi. Selinker (1972: 87) aduce în discuție un ,sistem lingvistic autonom", interlanguage, ,, an idiolect that has been developed by a learner of a second language which preserves some features of their first language and can also overgeneralize some L2 writing and speaking rules". Această interlimbă se caracterizează prin „fosilizare”, „linguistic items, rules and subsystems which speakers of a particular native language will tend to keep in their interlanguage, no matter what the age of the learner or amount of explanation or instruction he receives in the target language" (Selinker, 1972: 87). Cu toate acestea, apreciem că lingvistica contrastivă a avut un rol definitoriu în dezvoltarea didacticii moderne, a traductologiei și chiar în conturarea unor aspecte ce țin de domeniul lingvisticii tipologice. Greenberg, Comrie, Konig sau Hawkings aduc în discuție interfața dintre cele două abordări: ,to subsume discrete and apparently unrelated grammatical contrasts between the two languages under one overarching generalization." (Hawkings, 1986: 120)

In secolul trecut, un punct de reper în redimensionarea teoriilor despre analiza contrastivă 1-a constituit stabilirea unei mărimi relative, un ,sistem corelativ“, decodat ca o limbă-etalon, ,care reflectă segmentul comun din structura de profunzime a limbilor comparate". În acest fel, alături de lingvistica contrastivă tradiţională, unidirecţională, se poate constitui un al doilea tip, anume lingvistica contrastivă bidirecţională (Comrie, 1985). Se conturează astfel noua direcție în care evoluează analiza contrastivă: având în vedere 
că sistemul limbilor narurale nu este unul monolitic, ci, mai cu seamă,,an orchestration of different diasystematic varieties" (Comrie, 1985), este firesc ca el să fie adaptat situațiilor pragmatice de comunicare. Înțeles astfel, raportul comunicativ între idiomuri a dus, inevitabil, la constituirea unui alt domeniu în interiorul lingvisticii contrastive, anume pragmatica contrastivă, care își propune să reconfigureze perspectiva universalistă prin urmărirea manifestării naturale a actelor dialogice, prin implicarea variabilelor socioculturale și chiar sistemele nonverbale - transfer cultural (Espagne, 1999).

În acest tumult al direcțiilor de cercetare a limbajului, s-au făcut și delimitări, credem noi, uneori forțate. Un singur exemplu, ar fi trasarea unei linii clare de demarcație între lingvistica contrastivă (știință teoretică) și analiza contrastivă (orientare exclusiv aplicată), sau între analiza contrastivă și, un termen cvasi-sinonim, analiza confruntativă, o componentă a lingvisticii comparate, care ar cerceta limbile după criterii tipologice.

Orice demers didactic în sine de predare a unei limbi străine având ca limbă suport limba maternă a subiecţilor învăţării, este, implicit, o formă de analiză contrastivă,deoarece sunt vizate contrastele şi analogiile interlingvistice, indiferent dacă fac parte din aceeași familie de limbi sau nu. În funcţie de perspectiva din care este efectuată analiza, s-au conturat două procedee diferite din punctul de vedere al metodei de abordare a analizei contrastive: primul, orientat într-o singură direcţie, propune realizarea demersului contrastiv fără ca analiza să se sprijine pe un termen comun de comparaţie, iar al doilea presupune examinarea categoriilor lingvistice într-o dublă direcţie, cu sprijinul unui termen-barometru, abstract, cu valoare metalingvistică. Având în vedere caracterul didactic, aplicat al lucrării am optat pentru a doua metodă, comparând doar acele fapte lingvistice din limba armeană şi română cu relevanţă pentru eficientizarea învăţării limbii române de către vorbitorii de limbă armeană care nu beneficiază de o altă limbă suport. Tot din raţiuni pragmatice, am acordat o mai mare atenţie deosebirilor decât asemănărilor, însă nu am neglijat relevarea convergenţelor care acţionează ca o motivaţie suplimentară în învăţare.

În contextul actual al globalizării, al dinamicii complexe a dezvoltării sociale și al reorientării înspre Occident, armenii au devenit tot mai conștienți de necesitatea și utilitatea învățării limbilor străine, alta decât rusa: „Learning a foreign language in which it is possible to communicate with other nations is traditionally rooted in the school syllabi and curricula of so called small nations" (Ondrakova, 2019: 109). Acest inteses a crescut în ultimele decenii odată cu renunțarea la statutul limbii ruse ca limbă obligatorie în școlile de stat.

Începând cu 1991, popularitatea limbii engleze a crescut exponențial. În urma unui sondaj din 2012 a rezultat că $40 \%$ dintre armeni au cel puțin cunoștințe de bază a limbii engleze, în timp ce mai puțini de $4 \%$ au afirmat că știu limba engleză la nivel de utilizator experimentat (The South Caucasus 
between the EU and the Eurasian Union, 2013). În anul 2008, Armenia devine stat membru asociat al Țărilor Francofone și astfel se creează tot mai multe oportunități de studiere a limbii franceze, italiene, spaniole, portugheze și, surprinzător pentru mulți, a limbii române. Université Française en Armenie, American University, Valeri Brusov University of Languages and Social Sciences, Yerevan State University oferă studenților programe de licență, masterat sau doctorat.

Studenții armeni învață limba română în context exo-lingvistic, în cadrul lectoratului de limba română de la Erevan. Universitatea „Valeri Brusov" este singura care oferă cursuri de limba română la nivel de licență, ca a doua sau a treia limbă străină, dar și cursuri opționale pentru studenții de la alte facultăți.

Date fiind contextul și finalitatea didactică a lucrării, am abordat selectiv probleme circumcise lingvisticii contrastiv-tipologice, presupunând examinarea noţiunilor de comparare sincronică, echivalenţă cu scopul de a determina izomorfismul, respectiv alomorfismul celor două limbi şi identificarea unor metode, structuri relevante pentru un demers didactic coerent, profund, ancorat în limba vorbită, circular şi eficient. Una dintre cele mai vechi limbi, ramură distinctă a familiilor limbilor indo-europene, armeana are propriul alfabet care conţine mai multe litere decât alfabetul limbii române şi nu este o limbă complet fonetică. Urmând traseul analizei contrastive lucrarea punctează, cu exemple, o serie de diferenţe între limbile armeană şi română, variind de la lipsa categoriei gramaticale a genului la substantive, de la faptul că unele cuvinte din cele două limbi aparţin unor părţi de vorbire diferite, până la folosirea în contexte gramaticale diferite a articolelor hotărâte şi nehotărâte. Am avut în vedere şi asemănările dintre cele două limbi, cum ar fi caracterul fonematic al acestora, consoanele și grupurile consonantice dure și fricative, vocalele centrale intermediare și închise $(\breve{a}, \hat{\imath})$, iotul similar celui din limba armeană prin ocurența într-un context limitat.

Problemele de morfologie şi sintaxă au fost abordate doar prin reliefarea segmentelor care ridică dificultăți didactice în învăţarea limbii române de către vorbitorii de limbă armeană. Există asemănări în ceea ce priveşte bogata flexiune nominală și verbală, marcată prin numeroase alternanțe fonetice, existența unor clase lexico-gramaticale de graniță (numerale, pronume, adverbe, interjecții) cu flexiune fluctuantă, structura regulată a numeralelor și modul de formare a acestora, articolul hotărât care se pune la sfârşitul cuvântului ca în limba română. Printre diferenţe amintim: regimul specific al genului gramatical al substantivelor, conjunctivul prezent (viitor în armeană), care îşi schimbă forma la toate persoanele, deşi terminaţiile seamănă cu cele ale verbelor insuficiente, timpul compulsiv viitor, care se exprimă prin cuvântul trebuie/ petq e şi verbul la conjunctiv viitor, existenţa cazurilor ablativ, locativ şi instrumental. Lucrarea demonstrează că metoda analizei contrastive este una eficientă şi necesară în demersul didactic amintit. 
Cu unele excepţii, vorbitorii nativi de limba armeană reuşesc să pronunţe fidel sunetele specifice limbii române, aceasta şi datorită faptului că alfabetul armean are mai multe litere decât alfabetul limbii române, cu un palier foarte diversificat de sunete: consoane și dublete consonantice oclusive, africate, lichide, atât laterale cât şi vibrante, cu vocale variind de la cele închise la cele cvasi-deschise. Unele litere sau grupuri de litere au o valoare fonetică diferită în limba armeană, astfel că, în predarea limbii române transliterarea, prin comparaţie, contribuie la îmbunătăţirea semnificativă a pronunţiei în cazul studenţilor începători. Problemele pe care le întâlnesc vorbitorii de armeană variază de la dificultatea distingerii între $\breve{a}$ şi $\hat{a}$, pronunţarea dură a iotului final, sau o deschidere incompletă în cazul diftongilor sau a triftongilor, până la înlocuirea involuntară a unor sunete cu variantele apropiate de limba armeană: $d z$ în loc dej, $k$ aspirat sau $c h / t c h$ în loc de $c$ şi altele.

Litera $g$ se pronunţă la fel ca în limba română (gură, găleată), însă în combinaţiile ge/gi se pronunţă ghe/ghi: gitem-ghitem. Astfel, la o primă lectură, un armean va citi, invariabil, Gheorghe în loc de George. Folosind demonstraţia directă sau cu reprezentări grafice, profesorul va prezenta, comparativ, grupurile de sunete care în limba română redau un singur sunet sau două sunete:ce, $c i, g e, g i, c h e, c h i$, ghe, ghi (de exemplu: cercetare - 9 litere/ 9 sunete; ceară -5 litere, 4 sunete). Apoi, prin problematizare, profesorul îi va motiva pe elevi să gândească independent şi productiv şi să găsească regulile care cer utilizarea fiecărei speţe: 2 sunete, 2 litere când ce este urmat de consoană, de vocală în hiat sau $e$ în poziţie finală -cercetare, licean, tace; respectiv 2 litere, 1 sunet, când urmează vocala $a$ în aceeaşi silabă -ceată. Gh se pronunţă $r$ graseiat, iar grupul $c h$ ca în limba spaniolă, un $h$ mai dur, fiind necesare o serie de exerciţii de corectare pentru a elimina pronunţii de genul $a$ ahrăţa sau hiftea. O atenţie deosebită trebuie acordată literelor $t, p, r, t$, care, în limba armeană, se pronunţă diferit în funcţie de poziţia în care apar, iar diferenţa dintre cele două tipuri de sunete este una extrem de fină, uneori insesizabilă pentru cei care nu vorbesc limba armeană. Un exemplu concret ar fi modul în care armenii pronunţă , $t$ ” din cuvântul „tigru”, asemănător consoanei th aspirat din limba engleză (thga/băiat, ca în teacher). La fel stau lucrurile cu litera $p$, pronunţată phă sau $t$, pronunţat ocluziv, neaspirat (Ashvaţ/ Dumnezeu). Pe de altă parte, trebuie discutat regimul special al literelor $e, i$, $o, u$ care notează atât vocalele cât şi semivocalele corespunzătoare, ortografia sunetului $\hat{\imath}$, sau modului în care litera $x$ poate reprezenta simultan două sunete:axă/exaspera.

Profesorul de limba română va organiza lecţii de consolidare bazate pe expunere, audiţii, conversaţie, exerciţii de repetiţie, recunoaştere şi justificare sau, comparativ cu limba armeană, de recunoaştere şi disociere. Obiectivul principal în aceste lecţii este familiarizarea studenţilor armeni cu cei peste douăzeci de diftongi (ascendenţi/descendenţi) ai limbii române, cu triftongii şi pronunţia hiatului (foarte rare în limba armeană:vreau, leoarcă, miei; vocale 
de acelaşi fel aflate în hiat - contraatac,alcool, sau diferite - aer, aortă, peisaj etc. Literele duble notează, de regulă în ambele limbi, o realitate fonetică fie că este vorba de vocale sau, în armeană, preponderent de consoane. Spre deosebire de armeană unde dublarea consoanei este rezultatul unui procedeu gramatical (Amenn, articol hotărât enclitic), în limba română este vorba fie de repetarea aceleiaşi consoane în cuvinte compuse şi în derivatele cu prefixe (înnora), fie de consoane diferite notate de aceeaşi literă (accelera-akcelera).

Spre deosebire de limba română unde, de la caz la caz şi fără existenţa unor norme limpezi de accentuare, cuvintele se pot accentua, în funcţie de numărul de silabe, pe ultima silabă, penultima, antepenultima, a patra sau chiar a cincea silabă de la final (măsea, albină, butelie, veveriţă, nouăsprezece), în limba armeană accentul cade pe ultima silabă a cuvintelor, cu excepţia celor care se termină în vocala $\breve{a}$, caz în care se accentuează antepenultima silabă, sau a substantivelor proprii străine (linel, zangel/ Lehastan). În limba română nu primesc accent articolele, formele neaccentuate ale pronumelor personale şi reflexive, verbele auxiliare, prepoziţiile sau interjecţiile. Limba armeană nu cunoaşte dubla accentuare, de aceea în lecţiile de consolidare trebuie acordată o atenţie sporită schimbărilor de accent care atrag, sau nu, schimbarea categoriei gramaticale: profesor/profesor; director/director; corector/corector şi altele. Aici includem şi verbele ale căror forme verbale se scriu identic, dar se pot accentua diferit, schimbarea de accent producând şi o schimbare a timpului verbal: Clientul reclämă că vânzătorul l-a tratat necorespunzător/ Proprietarul îşi reclamă chiriaşul pentru neplata utilităţilor.

Timpurile verbale şi diatezele necesită o atenţie specială în predarea oricărei limbi străine şi unităţi de învăţare cu lecţii sporite de aprofundare şi transfer. Limba armeană are doar două conjugări-verbe terminate la infinitiv în -el, respectiv - $a l$, iar modurile şi timpurile verbale, cele mai multe analitice, se formează cu verbul auxiliar linel/a fi. Dificultăţile pe care le pot întâmpina studenţii armeni în învăţarea timpurilor verbale sunt determinate de numeroasele excepţii existente în limba română, pe de-o parte, şi de prezenţa categoriei gramaticale a aspectului în limba armeană, pe de alta. De exemplu, în limba armeană timpul indicativ prezent se poate exprima şi prin terminaţia specifică participiului -ats, care înlocuieşte terminaţia de infinitiv la unele verbe, urmat de verbul auxiliar cu desinenţe specializate pentru fiecare persoană. În aceste cazuri particulare, participiul prezent arată rezultatul, situaţia în care se află deja subiectul, în timp ce verbul conjugat regulat denotă aspectul, procesul acţiunii care încă se desfăşoară, ca în exemplul: kagnum e (El se ridică, încă nu este în picioare.)/ kagnats e (Stă in picioare). Mai mult decât atât, în armeană, categoria aspectului cuprinde aproape toate cuvintele din clasa verbului, chiar dacă nu toate verbele exprimă aspectul în serii opozitive. În acest caz, pentru nivelul B1-B2, este necesară o unitate de învăţare separată, de aprofundare, din care să reiasă că în limba română, lipsind mijloacele formale, morfematice, care marchează opoziţia 
dintre aspecte în cazul aceluiaşi lexem,categoria gramaticală a aspectului are un regim special. Totuşi, aşa cum remarcă şi cercetătorul A. Mişan (1978: 27), se poate vorbi despre exprimarea aspectului şi în limba română, dar prin alte mijloace decât cele strict gramaticale. Verbele, care prin semantica lor exprimă felul desfăşurării acţiunii în timp, sunt elemente lexicale care au păstrat posibilitatea de a exprima diverse nuanţe aspectuale necesare pentru claritatea mesajului. Spre deosebire de limba armeană, în limba română sunt mai bine păstrate doar nuanţele durative şi momentane, cele durative având tangențe clare cu imperfectivitatea.

Conjunctivul prezent din limba română are drept corespondent conjunctivul/ subjonctivul viitor în limba armeană, care are desinenţe specifice pentru fiecare persoană. Spre deosebire de limba română, armeana foloseşte infinitivul după anumite verbe, doar dacă subiectul celor două verbe este acelaşi: uzel - a vrea/tankanal -a dori; Yes uzum em gnal/ Eu vreau să merg (a merge). Conjunctivul prezent (viitor în limba armeană) se foloseşte cu conjuncţiile $c a$ sau $c a$ să-vor, doar dacă subiectul celor două verbe este diferit: Duq uzum eq vor nranq khosen/Voi vreţi să vorbească (conjunctivul viitor khosen şi nu infinitivul hosel). În această speţă, profesorul trebuie să insiste prin comparaţie şi aplicat asupra diferenţelor în utilizarea conjunctivului, respectiv a infinitivului în cele două limbi (nu-i vine a credel nu-i vine să creadă; poate veni/ poate să vină etc), să aducă în discuţie posibilitatea şi cazurile de înlocuire a conjunctivului cu infinitivul în limba română, înlocuire care este marcată stilistic şi mai frecventă în stilul cultivat. De la nivelul B2 în sus se pot organiza lecţii suplimentare pentru a clarifica valorile conjunctivului perfect în cele două limbi în limba armeană acesta având forme diferenţiate pentru fiecare persoană.

În gramatica limbii armene există şi timpul compulsiv viitor, care se exprimă prin sintagma petq e/ piti urmată de verbul la conjunctiv viitor: Eu trebuie să merg/Yes petq e gnam. Spre deosebire de limba română, trebuie are numai sens modal, iar în construcţii cu valoare generală petq $e$ se foloseşte doar cu infinitivul: Petq e anel- Trebuie făcut (a face). Pentru a corecta situaţiile în care studenţii armeni au tendinţa de a folosi infinitivul şi în limba română, sunt necesare exerciţii de recunoaştere şi diferenţiere (trebuie să fac/ trebuie făcut) trebuie să fi făcutl trebuie a face astal trebuie a şti să vorbeşti etc.).

$\mathrm{Ca}$ şi limba română, armeana are un grad relativ mare de analitism, astfel că valoarea temporală de viitor este uneori exprimată nu numai prin forme specifice acestuia. Faţă de limba română care are patru forme de viitor propriu-zis şi una de viitor anterior, toate formate analitic, limba armeană are două variante de bază pentru exprimarea viitorului. Prima a evoluat de la forme personale analitice la forme sintetice,desinenţele provenind de la indicativul prezent al verbului linel-a $f$ (excepţie facând persoana a treia singular) care sunt adăugate la forma de infinitiv a verbului conjugat. Marca specifică acestui timp este consoana $k$, antepusă, care ramâne neschimbată. Armenii folosesc 
kgrem/kgres- o sa scriu/ o sa scrii doar pentru o acţiune imediată în viitor: Erku ropeickgrem qez-O să-ţiscriu în două minute. Viitorul simplu este analitic şi se formează prin adăugarea desinenţei $u$ la infinitiv, urmat de verbul auxiliar a $f i$ la indicativ prezent. Se foloseşte pentru acţiuni viitoare neimediate, dar şi cu verbe de mişcare în locul conjunctivului: Es greluem qez vax@ Îţi voi scrie mâine; Gnum em vor utem, devine Gnum em utelu - Mă duc să manânc. Pentru o înțelegere corectă a utilizării viitorului, profesorul de limba română trebuie să puncteze faptul că, spre deosebire de armeană, în limba română formele de viitor sunt distribuite şi după registre de limbă: viitor standard, curent, familiar sau regional (oi aduna; o să te cred; aveţi să scrieţi regulat). Pentru nivelurile B2 plus sau C1, se vor discuta şi formele nespecifice de exprimare a viitorului, care nu există în limba armeană: imperativul Dă-mi împrumut nişte bani; conjunctivul prezent folosit în mod absolut cu valoare de imperativ care vizează viitorul - Nu vreau să scriu!; infinitivul A nu se răsturna!

În limba armeană,articolele au o utilizare mult mai largă decât in limba română. Articolul hotărât este enclitic, adăugându-se $n$ cuvintelor care se termină în vocală sau ă celor terminate în consoană: girq-girqă-carte/ dzi-dzincal. De reținut este faptul că vorbitorii de armeană au tendinţa să articuleze cu articol hotărât şi substativele proprii, pentru că în armeană acest articol se foloseşte şi cu numele de persoane, oraşe, tări etc., chiar şi cu numele străine: Aram o aşteaptă - Aramă spasum e nran; Maria Stan dansează-Maria Stană parum e. De asemenea, pronumele negative, nehotărâte sau demonstrative primesc articol hotărât dacă îndeplinesc funcţia sintactică de subiect în propoziţie: Fiecare merge acasă. - Yuracancură gnum e tun. $\mathrm{O}$ altă diferenţă faţă de română şi care necesită clarificări suplimentare este folosirea articolului hotărât cu substantivele precedate de adjectivul pronominal demonstrativ: Acest cal - ays dzin; această carte - ays qirqŭ ; acel om-ayd mardă”.

Studenţii armeni întâmpină, de cele mai multe ori, dificultăţi şi la utilizarea articolului nehotărât, aceasta pentru că în armeană nu există reguli stricte privind folosirea acestuia. $\mathrm{O}$ greşeală des întâlnită este folosirea substantivului comun fără articol nehotărât ca în exemplul: Axchik gnum e qaraq - Fată merge în oraş., aceasta pentru că în armeană cuvântul în sine exprimă sensul nehotarât, numeralul mek sau articolul nehotărât $m i$ fiind folosite în varianta literară a limbii doar pentru a întări sensul nehotărârii. Sunt şi alte cazuri când folosirea articolului hotărât sau nehotărât diferă în cele două limbi: Îmi place fotbalul se traduce în armeană fără articolul hotărât Es sirum em futbol. Substantivul se articulează doar dacă este însoţit de un adjectiv sau un alt substantiv precedat de prepoziţie: Es sirumem Angliatsi futbolă. Sau, un alt exemplu în care folosirea articolului nehotărât este obligatorie în limba română, dar nu şi în armeană: Tesnum enq paharan yev sarnaran - Vedem (un) dulap şi (un) frigider.

Altă diferenţă majoră între cele două limbi este exprimarea sintetică a posesiei pentru persoanele I si a II-a singular, prin intermediul articolelor 
hotărâte enclitice, posesive:im girqŭ devine girqs - cartea meal ko anună devine anund - numele tău. De asemenea, în limba armeană se foloseşte articolul hotărât şi cu pronumele posesive genitivale: Al meu este frumos Im $\breve{a}$ sirun e.

Limbă flexionară, armeana a păstrat opt cazuri (nominativ, vocativ, acuzativ, genitiv, dativ, ablativ, instrumental şi locativ), deşi cazurile nominativacuzativ, genitiv-dativ, dativ-ablativ-vocativ nu se deosebesc întotdeauna prin formă, distingându-se prin funcţiile sintactice sau lipsa acestora. Astfel, în armeană vocativul se exprimă prin forme specifice cazului nominativ fără articolul hotărât, iar accentul, marca vocativului, se pune întotdeauna pe ultima silabă: Tghaner! - Băieţi!/ Axjik! - Fato!”. Armenii nu folosesc însă foarte des formele de vocativ fără determinant, pentru că exprimă duritate. Prin urmare, apelativele în vocativ sunt însoţite de adjectivele jan sau sireli- formal: Tgha jan! - Băiete/Băiatule dragă!’.

$\mathrm{O}$ atenţie deosebită trebuie acordată predării cazului genitiv, fiindcă joacă un rol semnificativ în numeroase structuri gramaticale, iar declinarea substantivelor se face complet diferit faţă de limba română. Diferenţa majoră, dincolo de alternanţele fonetice cu multe excepţii, constă în faptul că în armeană există prepoziţii sau locuţiuni prepoziţionale folosite cu genitivul sau acuzativul, care în limba română cer doar cazul acuzativ: sub dulap paharani tak/ faţă de soţ-amusnu handap/în vin-ginu meq etc. Astfel, pentru studenţii de nivel mediu sau avansat, sunt necesare lecţii de aprofundare în care să se explice, comparativ, regimul specific al genitivului. De exemplu, profesorul de limba română poate alcătui fişe de lucru în care să exemplifice regimul special al prepozițiilor cu/pentru-het/hamar în cele două limbi: indz het/qez hamar - cu mine/pentru tine, în ambele limbi se foloseşte forma de acuzativ a pronumelui, care în limba armeană coincide şi cu forma de dativ; Aleqsi hamar-pentru Alex, în armeană prepoziţia cere genitivul, în limba română, acuzativul. Alte exerciţii pot ilustra utilizarea diferită a articolului posesiv genitival din limba română, care în limba armeană se exprimă prin forma de genitiv a substantivului și prin articolul hotârăt: Este a lui Armen./ Armeninn e. Sau în structura: În cartea mare a lui Armen/Armeni mets qrqi meq, observăm forma de genitiv a ambelor substantive, în cazul primului utilizarea genitivului fiind obligatorie cu prepoziţia $m e q$ - $̂ n$, care în română cere acuzativul.

Clarificări suplimentare sunt necesare şi în predarea cazului dativ, care în armeană se aseamănă cu acuzativul. De exemplu, pronumele personal se declină în acelaşi fel atât la acuzativ, cât şi la dativ: mie/pe mine - indz; tie/pe tine - qez; nouă/pe noi-mez (Gitem qez/ Talis em qez - Te ştiu pe tinel Îti dau ţie). Şi în ceea ce privește substantivelor care denotă fiinţe, declinarea se face la fel la ambele cazuri, cu precizarea că în armeană desinenţa la forma nearticulată este aceeasi şi la genitiv: Ea scrie unui băiat - Na grum e mi tghayi; Ea iubeşte un băiat - Na sirum e mi tghayi. În lecţiile de aprofundare pentru grupele de 
avansaţi profesorul poate insista pe excepţiile şi alternanţele vocalice impuse de declinare, pe faptul că în limba română dintre substantive şi adjective au desinenţă de dativ numai femininele, aceleaşi la singular şi plural şi comune cu genitivul şi cu nominativul plural: unei/unor case/cafele. De remarcat este că desinenţa $e$ este întâlnită şi la neutru plural, iar $i$ şi la masculin, şi la neutru plural. În română au formă de dativ şi articolele, pronumele sau adjectivele pronominale. Dativul se distinge mai clar datorită articolelor şi adjectivelor pronominale ce determină substantivele, deşi formele de dativ ale acestora sunt, şi ele, comune cu genitivul: unui pom/unor scaune/televizorului/pomilor etc. Lecţiile de transfer vor familiariza studenţii cu faptul că în limba română dativul este, în primul rând, cazul complementului indirect de atribuire, care, spre deosebire de armeană, apare fără prepoziţie sau postpoziţie, dar şi cazul specific verbelor al căror sens este legat de ideea generală de a da: I-am dat mamei adresa directorului adjunct. De asemenea, dativul poate avea în limba română şi sens posesiv (armeana nu exprimă posesia prin dativ), moştenire a dativului din latină, în expresii verbale ca: mi-e dor/mi-e foame/mi-e sete etc.

În limba armeană, ablativul este cazul circumentelor circumstanţiale şi exprimă punctul de plecare în spaţiu, sensul separării, despărţirii, cauza unei acţiuni şi altele. În această speţă, profesorul de română va prezenta comparativ complementele circumstanţiale și modalităţile de exprimare a acestora, cu regimul specific acuzativului în română, respectiv a cazului ablativ în armeană: Vertnum em mi qirqInayiţ (formă de ablativ) $u$ ir ankeruhuţ - Iau o carte de la Ina şi de la prietena ei. Prepoziţiile specifice ablativului din limba armeană cer, invariabil, acuzativul în limba română: Vine de acolo- Galis e ayntheriţ/ O să spun după el - Kasem nraniţ heto.

Cazurile instrumental şi locativ se formează sintetic prin adăugarea desinenţei -ov, respectiv -um la substantiv: girkov-cu cartel dziov-cu calul. Discutarea celor două cazuri se poate face simultan cu predarea prepoziţiei, stabilind rolul important al acesteia în limba română: facilitează relaţii sintactice, raporturi de dependenţă a atributului faţă de substantiv, a complementului faţă de verb, rolul deosebit în formularea unor exprimări clare, concise etc.

Deşi competenţa lingvistică de limba engleză ca limbă suport a devenit aproape o condiţie sine qua non în procesul de predare/învăţare a unei limbi străine, folosirea limbii materne a subiecţilor învăţării pentru relevarea prin contrast a izomorfismului, respectiv a alomorfismului celor două limbi, constituie un reper solid în predarea eficientă, circulară şi ancorată în limba actuală, practică, vorbită, reusindu-se astfel surprinderea, cu o mai mare acurateţe, a subtilităţilor celor două limbi şi eliminarea într-o mai mare măsură a neclarităţilor cauzate de structura diferită a acestora.

Metoda analizei contrastive este, aşa cum am arătat, un instrument ce serveşte la elaborarea unui parcurs didactic coerent, permite selectarea și analiza plurinivelară şi din diferite puncte de vedere a conţinuturilor învăţării şi centrarea acesteia pe formarea de abilităţi adaptate nevoilor şi experienţelor de 
învăţare ale vorbitorilor de limbă armeană. Experienţa didactică a demonstrat că în lecţiile în care sunt prezentate asemănările şi deosebirile dintre română şi armeană urmate de exerciţii de recunoaştere, aprofundare şi transfer, obiectivele au fost atinse mai uşor, iar transliterarea, exemplele şi referinţele la faptele de limbă şi structurile specifice limbii armene au avut rolul de a motiva, de a stârni curiozitatea şi de a stimula interesul pentru limba şi cultura română. Pe de altă parte, metoda analizei contrastive permite, în combinaţie cu demonstraţia, problematizarea, brainstormingul, crearea unor lecţii interactive, prin lucrul în echipă, prin tehnici comunicative care înlocuiesc sarcinile de învăţare frontale, consecutive, clasice.

\section{Referințe bibliografice:}

1 *** (2000) Gramatica limbii române, Vol. I. Cuvântul, Valeria Guţu-Romalo (coord.), Tiraj nou, revizuit, Editura Academiei Române, Bucureşti.

2. Abełyan, M., Hayoc' (1965), Lezvi tesut'yun (Theory of Armenian Language), Haykakan SSH GA hratarakč'ut'yun, Erewan.

3. Abrahamyan, S.G. Sevak, G.G., Hayoc' (1973),Lezvi zargac'umě sovetakan $\check{s} r j$ 'anum (The development of Armenian Language in Soviet period),Haykakan SSH GA hratarakč'ut'yun, Erewan.

4. Abrahamyan, S.G. (1975),Žamanakakic' hayereni k'erakanut'yun (Grammar of Modern Armenian), Luys, Erewan.

5. Ałayan, E. (1981), Žamanakakic' hayereni holovumĕ ew xonarhumĕ (The declension and conjugation of Modern Armenian), Haykakan SSH GA hratarakč'ut'yun, Erewan.

6. Arakelyan, V.D. Xačatryan, S.H. Ēloyan, S.A. (1979), 'Žamanakakic' hayoc' lezu' în Hator A. Hnč'yunabanut'yun ew bar agitut'yun (Modern Armenian. I. Phonology and Lexicology), Haykakan SSH GA hratarakč'ut'yun, Erewan.

7. Comrie, Bernard (1986), Contrastive Linguistics and Language Typology, de Gruyter, Berlin.

8. Comrie, Bernard (1976), Aspect: An Introduction to the Study of Verbal Aspect and Related Problems, Cambridge University Press.

9. Connor, Ulla (1996), Contrastive Rhetoric: Cross-cultural Aspects of SecondLanguage Writing, CUP.

10. Corder, Pit (1961), 'The significance of learner's errors' in International Review of Applied Linguistics. Oxford.

11. Corder, Pit (1981), Error Analysis and Interlanguage, Oxford University Press,

12. Cristea, Teodora (1977), Éléments de grammaire contrastive, București, Tipografia Universității din Bucureşti.

13. Dum-Tragut, Jasmine (2009),Armenian. Modern Estern Armenia, JB Publishing, Olanda.

14. Fillmore, Charles, J. (1972), 'The Case for Case', vol. Universals in Linguistic Theory, Editura Bach and Harms, Londra.

15. Fries, Charles Carpenter (1945), Teaching and Learning English as a Foreign Language, University of Michigan Press, Michigan.

16. Gass, Susan and Larry Selinker (1983), Language Transfer in Language Learning, Rowley MA, Newbury House. 
17. Iordan, Iorgu, Guțu Romalo, Valeria, Niculescu, Alexandra (1967), Structura morfologică a limbii române contemporane, Ed. Ştiințifică, Bucureşti.

18. Jacek, Fisiak (1981), Contrastive Linguistics and the Language Teacher,Pergamon, Oxford.

19. James, C. (1980), Contrastive analysis, Longman, London.

20. James, C. (1998), Errors in Language Learning and Ese, Harlow Addison Wesley, Longman.

21. Johnson, S. (1975), Papers in contrastive linguistics and language testing, C.W.C. Gleerup, Lund.

22. Krzeszowski, Tomasz P. (1990), Contrasting Languages. The Scope of Contrastive Linguistics, Walter de Gruyter \& Co., Berlin.

23. Lado, Robert (1957), Linguistics Across Cultures: Applied Linguistics for Language Teachers, University of Michigan Press,Michigan.

24. Nemser, William (1992), 'Approximative Systems of Foreign Language Learners', in Error Analysis. Perspective on Second Language Acquisition, Jack C. Richards (ed.), Longman, London and New York.

25. Nickel, G. (1971), 'Contrastive Linguistics and Foreign Language Teaching', în Papers in Contrastive Linguistics, Cambridge University Press.

26. Pârlog, Hortensia, Popa, Mariana (1983), Studii de analiză contrastivă a limbilor engleză şi română, Tipografia Universității din Timişoara, Timişoara.

27. Pop, Gheorghe (1998), Morfologia limbii române. Structuri şi sistem, Ed. Casa Cărții de Ştiință, Cluj-Napoca.

28. Rivers, Wilga (1979), 'Contrastive Linguistics in Textbook and Classroom', in E.T.F., No.7, Londra

29. Selinker, L. (1992), 'Interlanguage', in Error Analysis. Perspective on Second Language Acquisition, Jack C. Richards (ed.),Longman, London and New York. Hague.

30. Weinreich, U. (1963), Languages in Contact: Findings and Problems, The

31. Wekker Herman (1998), 'Contrastive Grammar: theory and practice' în Papers and Studies in Contrastive Linguistics, Walter and Gruiyter, Berlin.

32. White, L. (1989), Universal grammar and second language acquisition, University Press, Amsterdam.

33. Wierzbicka, Anna (1992), Cross-Cultural Pragmatics: The Semantics of Human Interaction, de Gruyter, Berlin. 